\title{
Developing Jemparingan Tradition-Based and Android- Assisted Learning Media for Improving the Graphic and Vector Representation Ability
}

\author{
https://doi.org/10.3991/ijim.v13i05.9926 \\ Merdu Raras, Heru Kuswanto ${ }^{(凶)}$ \\ Universitas Negeri Yogyakarta, Yogyakarta, Indonesia \\ herukus61@uny.ac.id
}

\begin{abstract}
This study aimed to (1) Develop jemparingan tradition (JEMASIK)-based and android-assisted learning media and (2) reveal the effect of JEMASIK-based media to improve the graphic and vector representation ability on the sub-chapter of parabolic motion vector.

The subjects of the field test trial were 61 students, consisting of 29 students in the control class and 31 students in the experimental class. The research results showed that there were differences between the experimental classes taught using JEMASIK-based media and the control class taught using Power Point media. The difference was proved by the multivariate test score of 0.000 less than 0.05 . The effectiveness of JEMASIK-based media was shown by the gain score in the pretest and posttest. The gain score of the control class was 0.54 in graphical representation and 0.49 in vector representation, while that of the experimental class was 0.75 in graphical representation and 0.60 in vector representation. The study concludes that the developed learning media The developed learning media based on traditional culture, JEMASIK, fulfils the feasibility criteria. There is a significant difference between the teaching of physics using JEMASIK media and that using Power Point media. And also, JEMASIK teaching media has a positive impact on the improvement of the graphic and vector representation ability.
\end{abstract}

Keywords-Android, JEMASIK, graphic representation, vector representation

\section{Introduction}

Problem solving skills are a complex part of physics learning [1]. Students are stated as having a problem solving skill when they have a good ability/skill of verbal, mathematical, vector describing, diagram and graphical representation abilities [2][3][4]. Graphical and vector representations are part of the problem solving skill. Students are required to represent graphs and vectors to solve the physical matters. However, many high school and university students have difficulties in representing graphs and vectors in physics subject [5][6] [7] [8]. Their graphic representation ability in the form of ability to read, draw and interpret, is in the low category [9][10] [11]. In vector representation, they use more mathematical concepts than physics 
concepts [12] [13]. Errors in representing the vectors are caused by their inability to understand vectors and anti-vectors, mathematical operation, outlining vectors, and angles in vectors [14].

Physical materials especially in parabolic motion require the graphic and vectors representation ability. The students who are unable to represent graphics and vectors on parabolic motion will have difficulty in learning parabolic motion. Their difficulties may lead them to failure in achieving the learning goal in the sub-chapter of parabolic motion vector. Prescott and Mitchelmore [15] observe students' errors in giving reasons for the location and magnitude of variable $\mathrm{X}$ and $\mathrm{Y}$ of ball's motion on the parabolic track. The students still fail to understand the basic concepts of parabolic motion [16] [17] [18] [19] [20].

Parabolic motion is closely related to everyday life, such as Jemparingan tradition, which is a traditional archery art in Yogyakarta and Central Java. Jemparingan is different from the archery sport in general because the archers are required to sit in a cross-legged position and to wear traditional Javanese clothing. This tradition is the local culture of Indonesia. Local culture is a property that has an emotionally binding power [21]. However, the young generation in Indonesian today begin to ignore their local culture [22]. The efforts to preserve the nation's culture may be conducted through teaching associated with culture [23] [24] because culture is transmitted from generation to generation [25]

Due to the difficulty in time, means, and infrastructures, introducing the local culture to the young generation becomes an obstacle, and it needs an innovation to cope with the problems. Learning must run well in the classroom [26]. The obstacle may be coped with by utilizing the learning media. Learning media become a solution to difficulties in learning [27][28]. In addition, the learning media should increase the students' desire to learn [29]. Nowadays, almost all high school students use the Android as a means of communication. The use of Android in learning may become a learning innovation [30][31]. Students are more interested in using M-Learning in the Android than e-learning [32]. Another benefit of the use of Android as learning material is learning can take place anywhere [33]. In learning, Android also assists the students to interact and do tasks [34][35].

Android as a medium of physics learning should contain the Jemparingan tradition as an introduction to the culture of Yogyakarta. Learning should also improve the representation of graphics and vectors. JEMASIK (Jemparingan Applied Physics) is a medium of physics learning. JEMASIK tries to improve the representation ability of graphics and vectors in the sub-chapter of parabolic motion vector. JEMASIK also introduces Jemparingan as Indonesian culture. This research develops a JEMASIK valid learning media and explains its effectiveness. 


\section{Research Method}

\subsection{General background of research}

This research is research and development which aims to develop the Jemparingan tradition-based and android-assisted learning media, and to assess the effectiveness of the developed media. The research used the 4-D model (define, design, develop, and disseminate) [36].

\subsection{Sample of research}

The sample of the study was divided into four stages. The first stage (validation) involved two expert lecturers, three physics teachers, and five peers. The second stage was an individual test to know the validity and reliability of the tasks, which involved a total sample of 246 students of two schools, consisting of 126 students of SMA N 2 Bantul, and 120 students of SMA N 3 Bantul. The third stage was the limited trial which involved nine students of three high schools, consisting of three students of SMA N 1 Sewon, three students of MAN 2 Yogyakarta, and three students of SMA N 1 Imogiri. The schools' sampling was qualified; MAN 2 Yogyakarta is located in the urban area, SMA N 1 Imogiri is located in the rural area, and SMA N 1 Sewon is on the outskirts of city. In addition, nine students were chosen because of their interest in learning media. They were asked to fill out a questionnaire about the quality of JEMASIK learning media. The fourth stage was field trials involving 61 grade $\mathrm{X}$ students of SMA N 1 Bantul, consisting of 29 students in the experimental class and 32 students in the control class. The class sampling was through the student analysis, including the analysis of their academic achievement, cognitive ability, problem solving skill, and socializing skill.

\subsection{Instrument and procedures}

The research instruments are a question list for observation, questionnaire, and tests. The questionnaire was used to determine the feasibility of the product which consisted of lesson plans, JEMASIK learning media in Android, and tasks about the representation of graphics and vectors. The questionnaire used the five-point Likert scale according to the rubric. Prior to spreading, the questionnaire was validated by an expert.

The graphic and vector representation test consists of a pretest and posttest. It is a multiple choice question test. Its scoring used the politomous scale, in which the score of 4 is given if the answer is correct and the reason is right, score of 3 if the answer is wrong but the reason is right, score of 2 if the answer is correct but the reason is wrong, and score of 1 if the answer is wrong and the reason is wrong. The tasks are developed in accordance with the core competence, basic competence, and indicators of physics learning. And, the directions of the graphical representation test is presented in Table 1 below, and the directions of the vector representation test is presented in 
Table 2. Both types of tasks were validated by material experts, and then individual trials were done.

Table 1. Directions of Graphical Representation Test.

\begin{tabular}{|c|c|c|c|c|c|c|}
\hline \multirow{2}{*}{ No. } & \multirow{2}{*}{ Sub-Chapter } & \multicolumn{4}{|c|}{ Cognitive Aspects } & \multirow{2}{*}{\begin{tabular}{|c|c|} 
Total number \\
of Tasks
\end{tabular}} \\
\hline & & $C_{3}$ & $C_{4}$ & $C_{5}$ & $C_{6}$ & \\
\hline 1. & Analyzing the height of particle & 1 & 2 & & & 2 \\
\hline 2. & $\begin{array}{l}\text { Understanding the high changes due to } \\
\text { certain factors }\end{array}$ & 3 & 4,5 & & & 3 \\
\hline 3. & $\begin{array}{l}\text { Matching and understanding the } \\
\text { narrative information in graphs }\end{array}$ & & 6 & & $7,8,9,10$ & 5 \\
\hline 4. & $\begin{array}{l}\text { Determining the size of a variable if } \\
\text { other variables are known }\end{array}$ & 11 & 12 & 13 & & 3 \\
\hline 5. & Determining the velocity score & 14 & & 15 & & 2 \\
\hline 6. & $\begin{array}{l}\text { Understanding the factors that cause } \\
\text { an object to be motionless }\end{array}$ & 16 & 17 & $18,19,20$ & & 5 \\
\hline Total & & 5 & 6 & 5 & 4 & 20 \\
\hline
\end{tabular}

Table 2. Directions of Vector Representation Test

\begin{tabular}{|c|c|c|c|c|c|c|}
\hline \multirow{2}{*}{ No. } & \multirow{2}{*}{ Sub-Chapter } & \multicolumn{4}{|c|}{ Cognitive Aspects } & \multirow{2}{*}{\begin{tabular}{|l|} 
Total of Task \\
\end{tabular}} \\
\hline & & $C_{3}$ & $C_{4}$ & $C_{5}$ & $C_{6}$ & \\
\hline 1. & Point and frame of particles motion & 1 & & & & 1 \\
\hline 2. & Movements and position changes in a particle & & 2,3 & 4,5 & 6,7 & 6 \\
\hline 3. & Analysis of velocity & 8 & & 9 & & 2 \\
\hline 4. & Factors causing a velocity & 10 & 11 & & & 2 \\
\hline 5. & The particles location in all directions & & 12 & 13 & 14 & 3 \\
\hline 6. & Position function influenced by time & 15 & 16 & 17 & 18 & 4 \\
\hline 7. & $\begin{array}{l}\text { Variables affecting the movement of the location of } \\
\text { particles }\end{array}$ & & & 19 & 20 & 2 \\
\hline Total & & 4 & 5 & 6 & 5 & 20 \\
\hline
\end{tabular}

\subsection{Data analysis}

The analysis of the results of the validation by experts, physics teachers and peers of the learning devices was conducted using Aiken's V [37]. And the results of the limited trials was also analyzed by using Aiken's V. The feasibility analysis of the graphic and vector representation instruments from individual tests conducted validity and reliability tests. The calculation of the empirical validation test with Quest program with criteria of item or task declared as fit with IFIT MNSQ limit model from 0.77 to 1.30 . Meanwhile, the empirical reliability was measured using Cronbach's Alpa. And lastly, the effectiveness of JEMASIK learning media in improving the graphical and vector representation ability was viewed from gain score [38].

The increase of the significance of graphical and vector representation after the teaching implementation in the experimental and control classes was viewed from the statistical test using the multivariate analysis. However, before conducting the multivariate analysis, the researcher found it necessary to assess the normality and homo- 
geneity tests. The normality test was done by using Mahalanobis analysis. In contrast, the homogeneity test was done by using the statistic test of Bos'x M. After the normality and homogeneity tests were fit, and the multivariate test followed.

\section{$3 \quad$ Results and Discussion}

\subsection{Results of research}

The define stage of the study was conducted at SMA N 1 Bantul through interviews and observation. It continued to the design stage by collecting materials in accordance with the Jemparingan tradition. The material was shown in Table 3. It was organized and loaded in Android. After the learning media was loaded in Android Jemparingan Tradition-based, the next stage was the develop stage. Advice from experts and peer was used as an input to improve the media. The revised media was tested through a limited test, and then continued to field trials. In field trials, the learning materials were limited only to parabolic motion. It was in accordance with the suitability of research time duration. The JEMASIK media was applied in the experimental class. In contrast, the control class used Power Point media. The power point media contained only parabolic motion explanations, and did not emphasize on graphical and vector representations. The power point also did not explain about the Jemparingan tradition.

Table 3. Development Directions

\begin{tabular}{|c|c|c|c|c|c|}
\hline \multirow[t]{3}{*}{ Indicators } & \multicolumn{5}{|c|}{ Material } \\
\hline & \multirow{2}{*}{\begin{tabular}{|c|}
$\begin{array}{c}\text { Kinematics } \\
\text { Motion by } \\
\text { Vector analysis }\end{array}$ \\
Vector analysis \\
of Parabolic \\
motion \\
\end{tabular}} & \multicolumn{3}{|c|}{ Energy } & \multirow{2}{*}{\begin{tabular}{|c|}
$\begin{array}{c}\text { Momentum and } \\
\text { Implus }\end{array}$ \\
Momentum \\
\end{tabular}} \\
\hline & & Kinetic Energy & $\begin{array}{c}\text { Potential Energy } \\
\text { (Elevation } \\
\text { factor) }\end{array}$ & $\begin{array}{c}\text { Potential Energy } \\
\text { (Elasticity fac- } \\
\text { tor) }\end{array}$ & \\
\hline $\begin{array}{l}\text { Analyze the } \\
\text { particle height }\end{array}$ & $\begin{array}{l}\text { Calculate and } \\
\text { analyze the high } \\
\text { magnitude } \\
\text { through graph }\end{array}$ & & $\begin{array}{l}\text { Calculate the } \\
\text { potential energy } \\
\text { by high particle } \\
\text { analysis through } \\
\text { graph }\end{array}$ & & \\
\hline $\begin{array}{l}\text { Understand the } \\
\text { high changes due } \\
\text { to certain factors }\end{array}$ & $\begin{array}{l}\text { Problem solving } \\
\text { related to high } \\
\text { magnitude due to } \\
\text { certain factors } \\
\text { through graphs }\end{array}$ & & $\begin{array}{l}\text { Determine the } \\
\text { high magnitude } \\
\text { through energy } \\
\text { equations with } \\
\text { the help of } \\
\text { graphs }\end{array}$ & & \\
\hline $\begin{array}{l}\text { Match and } \\
\text { understand the } \\
\text { narrative infor- } \\
\text { mation with } \\
\text { graphs }\end{array}$ & $\begin{array}{l}\text { Choose a suitable } \\
\text { graph appropri- } \\
\text { ate to the para- } \\
\text { bolic motion } \\
\text { issues }\end{array}$ & $\begin{array}{l}\text { Choose a suitable } \\
\text { graph appropri- } \\
\text { ate to kinetic } \\
\text { energy issues }\end{array}$ & $\begin{array}{l}\text { Choose a suitable } \\
\text { graph appropri- } \\
\text { ate to potential } \\
\text { energy issues }\end{array}$ & $\begin{array}{l}\text { Choose a suitable } \\
\text { graph appropri- } \\
\text { ate to potential } \\
\text { energy issues }\end{array}$ & $\begin{array}{l}\text { Choose a suitable } \\
\text { graph appropri- } \\
\text { ate to the issue of } \\
\text { momentum }\end{array}$ \\
\hline $\begin{array}{l}\text { Determine the } \\
\text { magnitude of } \\
\text { variables if other }\end{array}$ & $\begin{array}{l}\text { Calculate, ana- } \\
\text { lyze and predict } \\
\text { the angle, height }\end{array}$ & $\begin{array}{l}\text { Calculate the } \\
\text { magnitude of the } \\
\text { kinetic energy if }\end{array}$ & $\begin{array}{l}\text { Analyze the } \\
\text { graph, then } \\
\text { determine the }\end{array}$ & $\begin{array}{l}\text { Analyze the } \\
\text { graph, then } \\
\text { determine the }\end{array}$ & $\begin{array}{l}\text { Analyze the } \\
\text { graph of particle } \\
\text { velocity and }\end{array}$ \\
\hline
\end{tabular}




\begin{tabular}{|c|c|c|c|c|c|}
\hline \multirow[t]{3}{*}{ Indicators } & \multicolumn{5}{|c|}{ Material } \\
\hline & \multirow{2}{*}{ 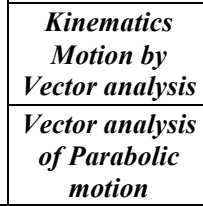 } & \multicolumn{3}{|c|}{ Energy } & \multirow{2}{*}{\begin{tabular}{|c|}
$\begin{array}{c}\text { Momentum and } \\
\text { Implus }\end{array}$ \\
$y$ \\
\end{tabular}} \\
\hline & & Kinetic Energy & $\begin{array}{c}\text { Potential Energy } \\
\text { (Elevation } \\
\text { factor) }\end{array}$ & \begin{tabular}{|c|} 
Potential Energy \\
(Elasticity fac- \\
tor)
\end{tabular} & \\
\hline $\begin{array}{l}\text { variables are } \\
\text { known }\end{array}$ & $\begin{array}{l}\text { and range of the } \\
\text { particle if other } \\
\text { variables are } \\
\text { known through } \\
\text { the graph of } \\
\text { parabolic track }\end{array}$ & $\begin{array}{l}\text { the velocity and } \\
\text { mass of the } \\
\text { particle are } \\
\text { known through } \\
\text { the graph }\end{array}$ & $\begin{array}{l}\text { magnitude of } \\
\text { potential energy } \\
\text { if the height and } \\
\text { mass of the } \\
\text { particle are } \\
\text { known }\end{array}$ & $\begin{array}{l}\text { magnitude of } \\
\text { potential energy } \\
\text { if the elasticity } \\
\text { constant and } \\
\text { change of parti- } \\
\text { cle length are } \\
\text { known }\end{array}$ & $\begin{array}{l}\text { determine the } \\
\text { momentum at the } \\
\text { velocity }\end{array}$ \\
\hline $\begin{array}{l}\text { Determine the } \\
\text { velocity }\end{array}$ & \begin{tabular}{|l} 
Determine and \\
interpret the \\
magnitude of the \\
initial velocity \\
and the velocity \\
at each position \\
through the \\
graph
\end{tabular} & $\begin{array}{l}\text { Determine the } \\
\text { velocity if the } \\
\text { kinetic energy } \\
\text { and particle mass } \\
\text { are known } \\
\text { through graph }\end{array}$ & & & $\begin{array}{l}\text { Determine the } \\
\text { final velocity of } \\
\text { the object } \\
\text { through the } \\
\text { quantity and } \\
\text { graph }\end{array}$ \\
\hline \begin{tabular}{|l|} 
Understand the \\
factors that cause \\
an objects are not \\
motionless
\end{tabular} & $\begin{array}{l}\text { Determine the } \\
\text { position of the } \\
\text { object and the } \\
\text { factor make the } \\
\text { object is in that } \\
\text { position through } \\
\text { graph }\end{array}$ & $\begin{array}{l}\text { Understand the } \\
\text { velocity and } \\
\text { energy of motion } \\
\text { as a result of } \\
\text { objects are not } \\
\text { motionless }\end{array}$ & $\begin{array}{l}\text { Understand the } \\
\text { magnitude of } \\
\text { height and } \\
\text { energy of motion } \\
\text { as a result of not } \\
\text { motionless } \\
\text { objects }\end{array}$ & $\begin{array}{l}\text { Understand the } \\
\text { amount of poten- } \\
\text { tial energy as the } \\
\text { factors that cause } \\
\text { an objects to be } \\
\text { not motionless }\end{array}$ & \\
\hline $\begin{array}{l}\text { Point and } \\
\text { framework of } \\
\text { particle }\end{array}$ & $\begin{array}{l}\text { Determine the } \\
\text { initial velocity } \\
\text { magnitude by } \\
\text { observing the } \\
\text { direction }\end{array}$ & & $\begin{array}{l}\text { Determine the } \\
\text { potential energy } \\
\text { by observing the } \\
\text { height of parti- } \\
\text { cles }\end{array}$ & & \begin{tabular}{|l|} 
Determine the \\
amount of initial \\
velocity before \\
the collision \\
occurs
\end{tabular} \\
\hline $\begin{array}{l}\text { Move and } \\
\text { change of posi- } \\
\text { tions on particles }\end{array}$ & $\begin{array}{l}\text { Understand the } \\
\text { coordinate point, } \\
\text { the magnitude of } \\
\text { the velocity in } \\
\text { terms of the axis } \\
\text { of } x \text { and } y\end{array}$ & $\begin{array}{l}\text { Understand the an } \\
\text { position change }\end{array}$ & mount of energy th & at changes due to & $\begin{array}{l}\text { Understand the } \\
\text { movement of } \\
\text { objects before } \\
\text { and after the } \\
\text { collision }\end{array}$ \\
\hline $\begin{array}{l}\text { Analyze the } \\
\text { velocity }\end{array}$ & $\begin{array}{l}\text { Analyze the } \\
\text { minimum veloci- } \\
\text { ty and velocity at } \\
\text { each position in } \\
\text { terms of the axis } \\
\text { of } x \text { and } y\end{array}$ & $\begin{array}{l}\text { Analyze the } \\
\text { velocity moment } \\
\text { to determine the } \\
\text { amount of energy }\end{array}$ & & & $\begin{array}{l}\text { Analyze the } \\
\text { velocity before } \\
\text { and after the } \\
\text { collision by } \\
\text { observing the } \\
\text { direction }\end{array}$ \\
\hline $\begin{array}{l}\text { Factors of Veloc- } \\
\text { ity making }\end{array}$ & $\begin{array}{l}\text { Analyze and } \\
\text { complete the } \\
\text { image to deter- } \\
\text { mine the velocity } \\
\text { at a certain time } \\
\text { by observing the } \\
\text { horizontal and } \\
\text { vertical direc- }\end{array}$ & & & & $\begin{array}{l}\text { Determine the } \\
\text { factor causing } \\
\text { velocity changes } \\
\text { by observing the } \\
\text { direction of the } \\
\text { collision }\end{array}$ \\
\hline
\end{tabular}


Paper-Developing Jemparingan Tradition-Based and Android-Assisted Learning ...

\begin{tabular}{|c|c|c|c|c|c|}
\hline \multirow[t]{3}{*}{ Indicators } & \multicolumn{5}{|c|}{ Material } \\
\hline & \multirow{2}{*}{ 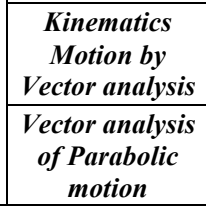 } & \multicolumn{3}{|c|}{ Energy } & \multirow{2}{*}{\begin{tabular}{|c|}
$\begin{array}{c}\text { Momentum and } \\
\text { Implus }\end{array}$ \\
$y$ \\
Momentum \\
\end{tabular}} \\
\hline & & Kinetic Energy & $\begin{array}{c}\text { Potential Energy } \\
\text { (Elevation } \\
\text { factor) }\end{array}$ & $\begin{array}{c}\text { Potential Energy } \\
\text { (Elasticity fac- } \\
\text { tor) }\end{array}$ & \\
\hline & tions & & & & \\
\hline $\begin{array}{l}\text { The location of } \\
\text { the particles } \\
\text { against all direc- } \\
\text { tions }\end{array}$ & $\begin{array}{l}\text { Analyze the } \\
\text { particle positions } \\
\text { both the } x \text { and } y \\
\text { axes }\end{array}$ & & $\begin{array}{l}\text { Determine the } \\
\text { high (the location } \\
\text { of the particles } \\
\text { against the y- } \\
\text { axis) }\end{array}$ & & \\
\hline $\begin{array}{l}\text { The position and } \\
\text { velocity equa- } \\
\text { tions affected by } \\
\text { time }\end{array}$ & $\begin{array}{l}\text { Determine the } \\
\text { coordinate and } \\
\text { velocity points } \\
\text { with the help of } \\
\text { time that particle } \\
\text { travels on the } \\
\text { point }\end{array}$ & & & & \\
\hline $\begin{array}{l}\text { Variables affect- } \\
\text { ing the position } \\
\text { shift of the } \\
\text { particle }\end{array}$ & $\begin{array}{l}\text { Complete a form } \\
\text { of position } \\
\text { equation when } \\
\text { the initial veloci- } \\
\text { ty, angle and } \\
\text { time are known }\end{array}$ & $\begin{array}{l}\text { Determine the } \\
\text { amount of energy } \\
\text { by the known } \\
\text { velocity as the } \\
\text { shifting factor }\end{array}$ & $\begin{array}{l}\text { Determine the } \\
\text { amount of poten- } \\
\text { tial energy as a } \\
\text { result of particle } \\
\text { shift }\end{array}$ & $\begin{array}{l}\text { Determine the } \\
\text { amount of poten- } \\
\text { tial energy as a } \\
\text { result of particle } \\
\text { shift }\end{array}$ & $\begin{array}{l}\text { Determine the } \\
\text { amount of mo- } \\
\text { mentum as a } \\
\text { result of object } \\
\text { shift }\end{array}$ \\
\hline
\end{tabular}

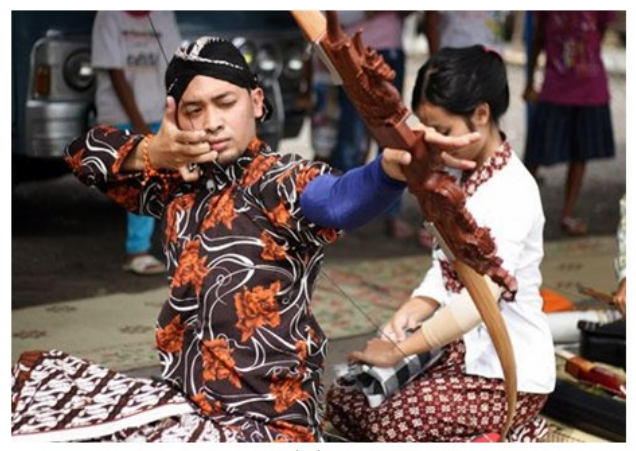

(a)

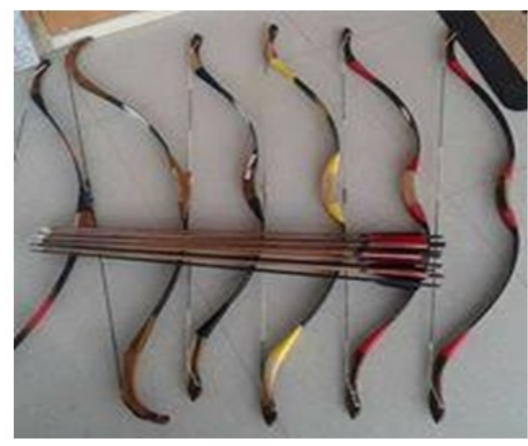

(b)

Fig. 1. (a). Position of Jemparingan Athlete, and Figure 1 (b). Equipment In Jemparingan Tradition 


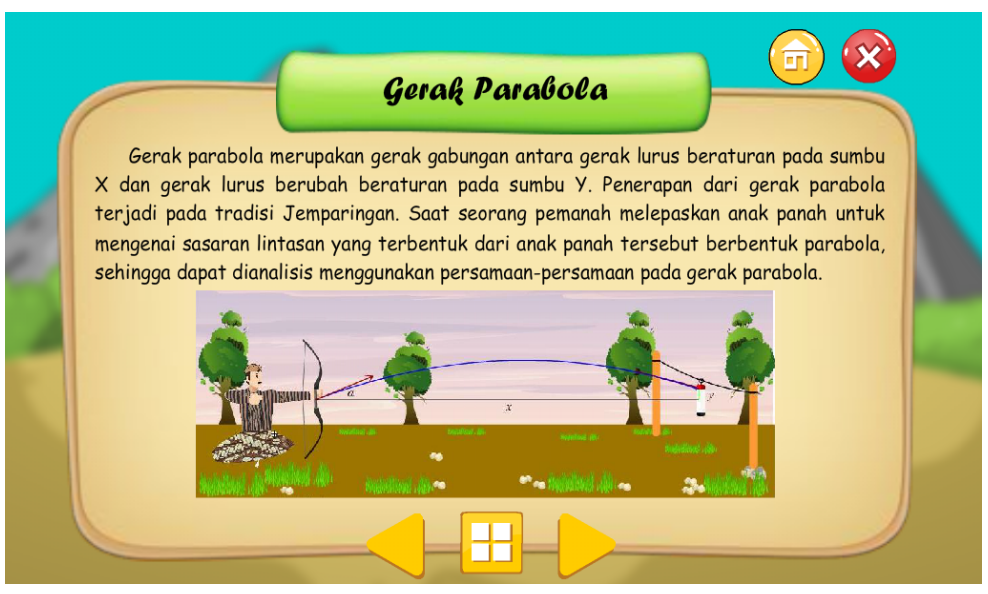

Fig. 2. The Relevance of Jemparingan Tradition with Physical Learning of Parabolic Motion Vector Analysis

Figures 1 and 2 are parts of the parabolic motion materials arranged in the Jemasik media. Figure 1 describes the parabolic trajectory of the arrow which is depicted in graphics. While Figure 2 explains the arrow modeling of the arrows analyzed in each point using vectors.

The emphasis of parabolic motion materials on graphical and parabolic representations is presented in Fig. 3.

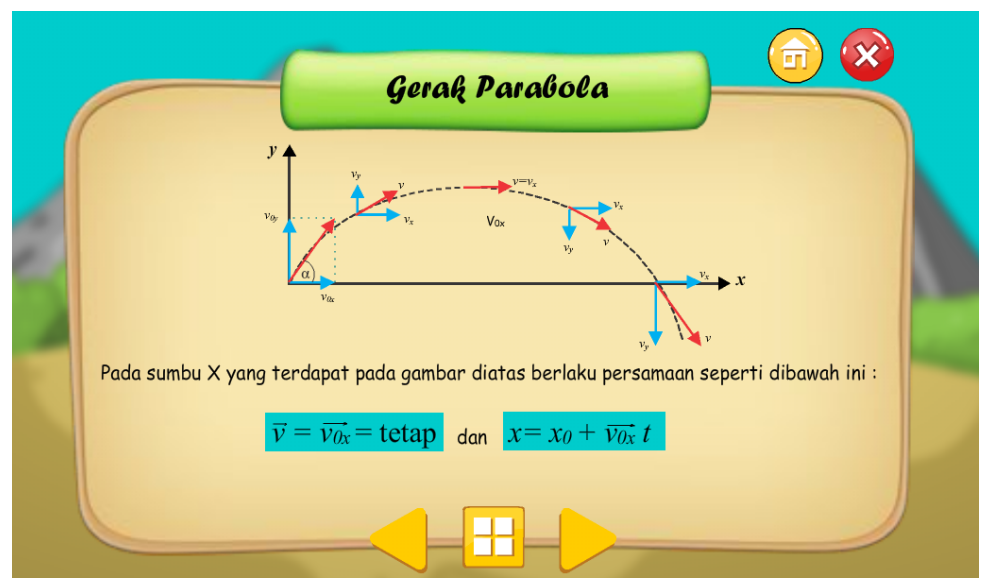

Fig. 3. Parabolic Motion Materials by displaying the graphics and velocity vectors to the $\mathrm{X}$ and Y axes

The validation result of learning device and instructional media is presented in Table 4 , where the entire result is very good, and thus the learning device and media may be applied to physics teaching. 
Table 4. Validation Result by Aiken's V

\begin{tabular}{|c|l|c|l|}
\hline No. & \multicolumn{1}{|c|}{ Learning Device } & Score of Aiken's V & \multicolumn{1}{|c|}{ Description } \\
\hline 1. & Lesson Plan & 0.97 & Very Good \\
\hline 2. & Learning Media & 0.93 & Very Good \\
\hline 3. & Task of Graphic Representation & 0.88 & Very Good \\
\hline 4. & Task of Vector Representation & 0.89 & Very Good \\
\hline
\end{tabular}

The validity test result in the individual test shows that Item19 on the task of the graphical representation and Item 20 on the task of vector representation were deleted because they did not meet the fit item requirement. The reliability of the graphical and vector representation task is presented in Table 5 where both represenatiton results show the high task reliability, which means that the task meets the criteria of reliability.

Table 5. Reliability of Graphic and Vector Representation Test

\begin{tabular}{|c|l|c|l|}
\hline No. & \multicolumn{1}{|c|}{ Task } & Score of Reliability & \multicolumn{1}{c|}{ Description } \\
\hline 1. & Graphical Representation & 0.81 & Very high \\
\hline 2. & Vector Representation & 0.80 & Very high \\
\hline
\end{tabular}

After the learning media were found in a very good category and the tests were valid and reliable, the teaching in the experimental and control classes was conducted. In the control class, the teacher used the power point media, while in the experimental class the teacher used the JEMASIK media. At the beginning and the end of the teaching, a pretest and posttest were administered. The results of the pretest and posttest are presented in Table 6 below.

Table 6. Pretest and Posttest Results of Experimental and Control Classes

\begin{tabular}{|c|c|c|c|c|c|c|}
\hline \multirow[t]{2}{*}{ No. } & \multirow[t]{2}{*}{ Representation } & \multirow[t]{2}{*}{ Criteria } & \multicolumn{2}{|c|}{ Experimental Class } & \multicolumn{2}{|c|}{ Control Class } \\
\hline & & & Pretest & Posttest & Pretest & Posttest \\
\hline \multirow[t]{4}{*}{1.} & \multirow[t]{4}{*}{ Graphics } & Average & 25.99 & 83.19 & 27.70 & 67.81 \\
\hline & & Standard deviation & 13.10 & 9.56 & 15.34 & 6.14 \\
\hline & & Highest Score & 48.75 & 100.00 & 51.25 & 85.00 \\
\hline & & Lowest Score & 0.00 & 63.75 & 0.00 & 57.50 \\
\hline \multirow[t]{4}{*}{2.} & \multirow[t]{4}{*}{ Vectors } & Average & 25.99 & 71.08 & 21.41 & 60.51 \\
\hline & & Standard deviation & 10.90 & 6.71 & 12.74 & 7.11 \\
\hline & & Highest Score & 35.00 & 82.50 & 35.00 & 75.00 \\
\hline & & Lowest Score & 0.00 & 60.00 & 0.00 & 42.50 \\
\hline
\end{tabular}

The multivariate analysis was used to reveal the effectiveness of using the JEMASIK media. However, before conducting the multivariate analysis, the researcher found it necessary to assess its normality and homogeneity. The normality test was done by using Mahalanobis analysis, while the homogeneity test was done by using the statistic test of Bos'x M. The result of the analysis of the normality and homogeneity tests is presented in Figure 4. After the normality and homogeneity tests were found fit, the multivariate test followed, and the result is presented in Table 7. 


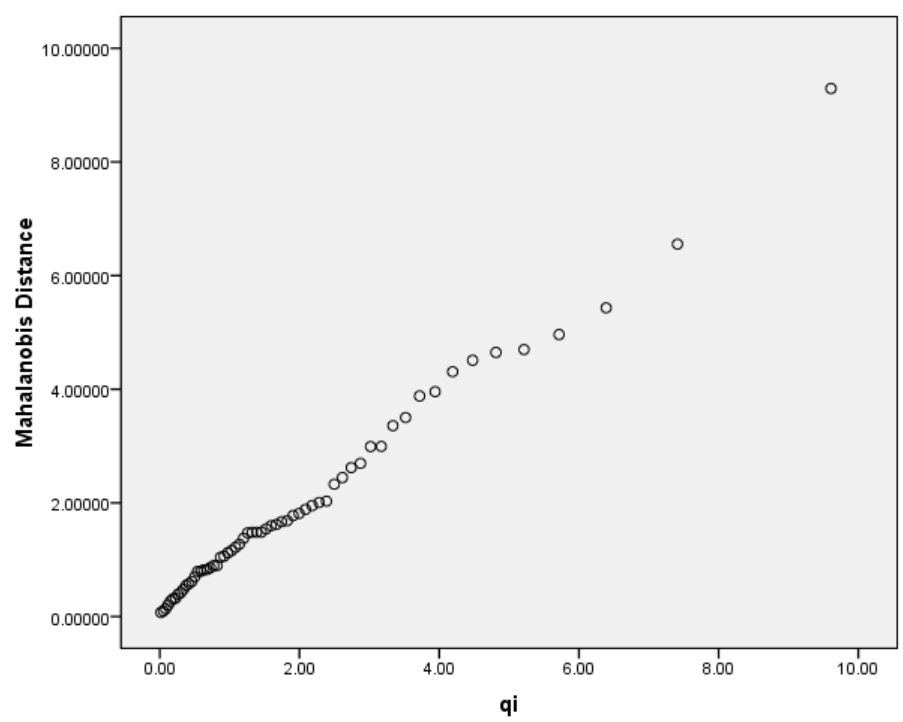

Fig. 4. Scatter-plot on Normality Test

Table 7. Box's Test of Equality of Covariance Matrices ${ }^{\mathrm{a}}$

\begin{tabular}{|c|c|}
\hline Box's M & 2.502 \\
\hline F & .803 \\
\hline df1 & 3 \\
\hline df2 & $9.289 \mathrm{E} 5$ \\
\hline Sig. & .492 \\
\hline
\end{tabular}

Figure 4 shows that the scattered data are normal and are shown by scatter-plots. The scatter-plot tends to make a straight line and more than $50 \%$ of the scores of the Mahalanobis distance are less than or equal to the qi score. Table 7 is the result of Bos's M test to determine the homogeneity test. The test results show that the graphic and vector representation ability shows a significance score of 0.492 , which is greater than 0.05 . Therefore, the result of normality test and reliability test is stated as fulfilling the requirement.

The completion of the prerequisite test is continued with the multivariate test. Table 8 shows that the hypothesis saying that there is a significant difference between the teaching using JEMASIK media and thatusing the Power Point media is accepted. It is shown by the significance score of Hotelling'S T2 of 0.000 which is less than 0.05 .

Table 8. Multivariate Tests

\begin{tabular}{|l|l|c|c|c|c|c|}
\hline \multicolumn{2}{|c|}{ Effect } & Score & F & Hypothesis df & Error df & Sig. \\
\hline Intercept & Hotelling's Trace & 35.916 & $1.042 \mathrm{E}^{\mathrm{a}}$ & 2.000 & 58.000 & .000 \\
\hline Grup & Hotelling's Trace & .737 & $21.373^{\mathrm{a}}$ & 2.000 & 58.000 & .000 \\
\hline
\end{tabular}


Gain score is used to know the improvement of the graphic and vector representation ability in each class. Figures 5 and 6 show the gain score of each class. It shows that the experimental class has a higher ability improvement than the control class. In sum, the use of the JEMASIK media has a positive impact.

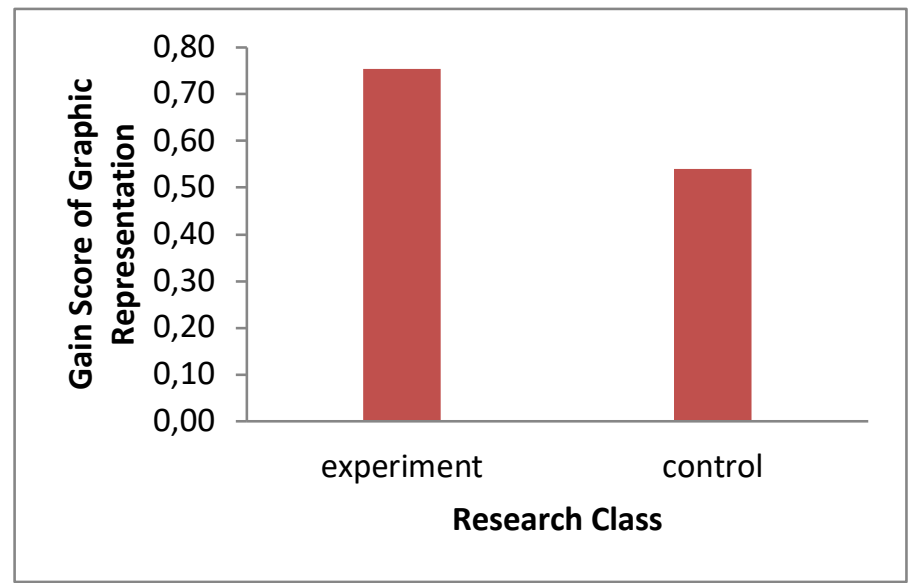

Fig. 5. Gain Score of Graphic Representation

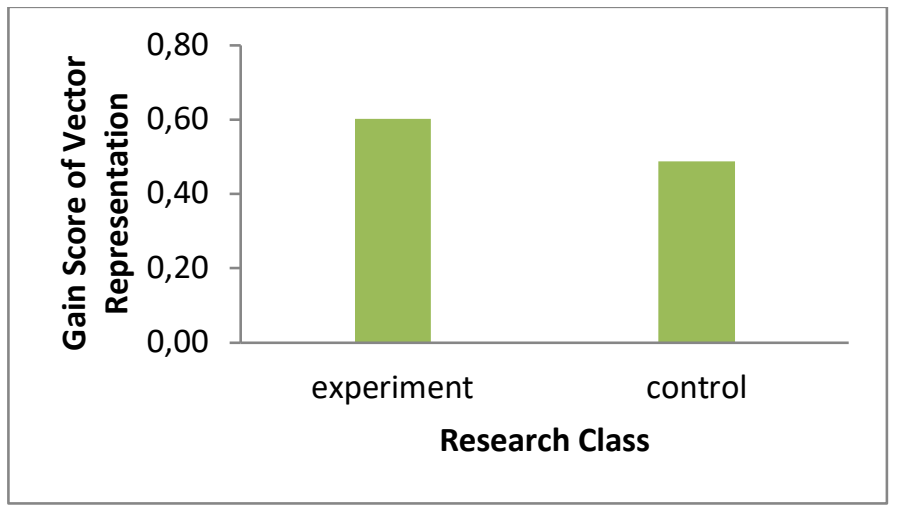

Fig. 6. Gain Score of Vector Representation

\subsection{Discussion}

In the first interviews with the teachers in the school, they stated that there were students' difficulties in problem solving. The problem solving ability primarily refers to graphic and vector representation ability. The students of State Senior High School (Sekolah Menengah Atas Negeri = SMAN) 1 Bantul actually have high cognitive ability. The finding is similar to the research by Allacaci, Lewis, O'Brien \& Jiang [39] and Bahtiyar \& Can [40], which found that students tend to have high cognitive ability but they find it difficult to do a task about graphic or vector representation. 
Moreover, after the interview, we found that the teachers only use the power point in teaching. The schools actually support the use of Android teaching media. This situation is supported by research of [41], which reported that there is a difference between the use of m-learning and e-learning. The Android-based media has advantage in teaching because Android can be used anytime and anywhere.

Another problem in the school is the lack of local cultural related to the teaching of physics. Teachers associate their teaching only to everyday events without involving local culture. Agustina \& Wahyudi's [42] research found that elementary school students are very interested in learning of culture through Android media. It is supported by Pamungka, Subali \& Lunuwih [43] who state that there are satisfactory results in an effort to improve student creativity through the local wisdom-based teaching. But, the research is applied to the science class and not in the physics class, and also, the teaching in the research is conducted directly without using Android media. It supports the use of instructional media involving local culture. Local culture-based teaching is able to grow the sense of love of the country.

From the findings, this research was designed to find out the effect of JEMASIK media use on the improvement of the graphic and vector representation ability on the sub-chapter of parabolic motion. There are two classes used in this research: the control and experiment classes. The most distinctive difference between these two classes is the use of JEMASIK media in the experimental class, whereas the control class does not use it. At the first meeting, a pretestwas administered to both classes. And, at the end of the meeting, a posttest was administered to both classes. The result of the analysis of the pretest and posttest results show that there is a difference between the experimental class and the control class. It is viewed from the significance of Hotelling's Trace score of 0.000 which is less than 0.05 , which means that there is a difference between the control class and the experimental class.

In terms of the gain score, the experimental class has a higher improvement than the control class for each representation. The class gain score on the graphic representation is 0.75 in the experimental class whereas in the control class the gain score is 0.54 . For the gain score in the vector representation of the experimental class is 0.60 whereas in the control class is the score is 0.49 . This means that there is a positive effect of the use of JEMASIK media on the improvement of the graphical and vector representation ability.

The results of this study are supported by the research by Ismail, Azizan \& Azman [44], which reported that after the use of m-learning, the learning outcome increased. With the various potentials and advantages it has, Mobile Learning is expected to be an alternative learning resource that can improve the efficiency and effectiveness of teaching processes and learners' learning outcomes. However, the application of mlearning must be balanced with adequate facilities and infrastructure. The existence of smartphones and Internet network is the main capital of the use of m-learning.

The research by Barniol, Zavala [8], Alkan, Erdem [45] and Kilic, Sezen, Sari [46], reported that students had difficulties learning the graphic and vector represenation in the sub-chapter of parabolic motion vector analysis. The finding of the research by Bunawan, Setiawan, Rusli \& Nahadi [11], which used a diagnostic test of optical material graph representation, showed that university students had difficulties analy- 
zing graphs, and their ability was dependent on the type of graphs and levels or types of questions. These difficulties may be minimized by the use of JEMASIK media. The integration of multiple representations may help students study physics [47]. The research by Sirait, Hamdani \& Oktavianty [48] reported the importance of the ability to represent vectors. In sum, learning physics requires not only a mathematical representation but also other representations such as graphic and vector representation.

The implementation of local culture should be strived to build students' love of the nation's culture. The research result by Suastra [24] showed that one of the suitable learning resources to support local culture-based science learning activities includes audio visual. In conclusion, the use of JEMASIK is very suitable for the teaching of physics on the sub-chapter of parabolic motion vector analysis

\section{Conclusion}

The developed learning media based on traditional culture, JEMASIK, fulfils the feasibility criteria. There is a significant difference between the teaching of physics using JEMASIK media and that using Power Point media. And also, JEMASIK teaching media has a positive impact on the improvement of the graphic and vector representation ability.

\section{$5 \quad$ References}

[1] Selcuk, G. S., Caliskan, S., \& Erol, M., (2008). The Effects of Problem Solving Instruction on Physics Achiement, Problem Solving Performance and Strategy Use. Lat. Am. J. Phys. Educ. 3. 151-66. https://dialnet.unirioja.es/descarga/articulo/2734595.pdf

[2] Ainsworth, S., (2008). Capter 9, The Educational Value of Multiple-representations when Learning Complex Scientific Concepts. Visualization: Theory and Practice in Science Education. 191-208. https://link.springer.com/chapter/10.1007/978-1-4020-5267-5_9. https://doi.org/10.1007/978-1-4020-5267-5 9

[3] Rojas, S., (2010). On the teaching and learning of physics problem solving. Revista Mexicana De $F^{\prime}$ Isica, 56. www.scielo.org.mx/pdf/rmfe/v56n1/v56n1a4.pdf.

[4] Docktor, J. L.\& Mestre, J. P. (2014). Synthesis of Discipline-Based Education Research in Physics. Physical Review Special Topics - Physics Education Research 10. 1-58. https://journals.aps.org/prper/pdf/10.1103/PhysRevSTPER.10.020119. https://doi.org/10.1103/physrevstper.10.020119

[5] Koedinger, K.R. \& Nathan, M.J. (2004). The Real Story Behind Story Problems: Effects of Representations on Quantitative Reasoning. The Journal of The Learning Sciences 13(2). 129-164.http://pact.cs.cmu.edu/pubs/Koedinger,Nathan-04.pdf.https://doi.org/10.1 207/s15327809jls1302 1

[6] Meltzer, D.E. (2005). Relation between students' problem-solving performance and representational format. Am. J. Phys 73. 463-478. http://physicseducation.net/docs /Relation_between_students.pdf. https://doi.org/10.1119/1.1862636

[7] Hawkins, J.M., Thompson, J.R., \& Wittmann, M.C. (2009). Students' Consistency of Graphical Vector Addition Method on 2-D Vector Addition Tasks. Physics Education Re- 
search Conference. 161-164. http://www.per-central.org/items/detail.cfm? $\mathrm{ID}=9471 \&$ Relations $=1$. https://doi.org/10.1063/1.3266704

[8] Barniol, P. \& Zavala G. (2014). Test of understanding of vectors: A reliable multiplechoice vector concept test. Physical Review Special Topics - Physics Education Research 10. 1-14. https://journals.aps.org/prper/pdf/10.1103/PhysRevSTPER.10.010121. https://doi.org/10.1103/physrevstper.10.010121

[9] Kohl, P.B. \& Finkelstein, N.D. (2006). Effect of instructional environment on physics students' representational skills. Physical Review Special Topics - Physics Education Research 2. 1-8. https://journals.aps.org/prper/pdf/10.1103/PhysRevSTPER.2.010102. https://doi.org/10.1103/physrevstper.2.010102

[10] Sezen, N., Uzun, M. S., \& Bulbul, A. (2012). An Investigation of preservice Physics Teachers' Use of Graphical Representations. Procedia - Social and Behavioral Sciences 46. 3006 - 3010. http://www.sciencedirect.com/ science/article/pii/S187704281201734X. https://doi.org/10.1016/j.sbspro.2012.05.605

[11] Bunawan, W., Setiawan, A., Rusli, A., \& Nahadi., (2015). Penilaian Pemahaman Representasi Grafik Materi Optika Geometri Menggunakan Tes Diagnostik. Jurnal Cakrawala Pendidikan,2.257-267. https://journal.uny.ac.id/index.php/cp/article/view/4830. https://doi.org/10.21831/cp.v2i2.4830

[12] Devender, J.V., \& Wittmann, M.C., (2008). Comparing Student Use of Mathematical and Physical Vector Representations. AIP Conference Proceedings. 1-4. www.percentral.org/document/ServeFile.cfm?ID=9110\&DocID=2023

[13] Haratua, T.M.S., \& Sirait, J. (2016). Representations Based Physics Instruction to Enhance Students' Problem Solving. American Journal of Educational Research 4. 1-4. http://pubs.sciepub.com/education/4/1/1/

[14] Susiharti \& Ismet., (2017). Studi Kesalahan Siswa dalam Menyelesaikan Soal-Soal Vektor di SMA Negeri 1 Inderalaya. Jurnal Inovasi dan Pembelajaran Fisika, 4. 99-105. http://ejournal.unsri.ac.id/index.php/jipf/article/view/4296.https://doi.org/10.25273/jems.v $\underline{4 i 1.200}$

[15] Prescott, A. \& Mitchelmore, M. (2005). Student Misconceptions about Projectile Motion. AE Prescott. 633-640. https://www.merga.net.au/documents/RP722005.pdf

[16] Bayraktar, S. (2009). Isconceptions Of Turkish Pre-Service Teachers About Force And Motion. International Journal of Science and Mathematics Education 7: 273-291. https://link.springer.com/article/10.1007/s10763-007-9120-

9.https://doi.org/10.1007/s10763-007-9120-9

[17] Dilber, F. Karaman, I. \& Duzgun, B. (2009). High school students' understanding of projectile motion concepts. Educational Research and Evaluation 15. 203-222. https://scihub.io/http://dx.doi.org/10.1080/13803610902899101.https://doi.org/10.1080/1380361090 $\underline{2899101}$

[18] Graham, T., Berry, J, \& Rowlandsa, S. (2013). Are 'misconceptions' or alternative frameworks of force and motion spontaneous or formed prior to instruction? International Journal of Mathematical Education in Science and Technology 44. 84-103. https://scihub.io/http://dx.doi.org/10.1080/0020739X.2012.703333.https://doi.org/10.1080/0020739x .2012 .703333

[19] Mudau, A.V. (2014). Pragmatic Review of Literature Associated with Projectile Motion Perceived as Difficult to Teach by Some South African Teachers. Mediterranean Journal of Social Sciences 5. 441-445. http://www.mcser.org/journal/index.php/mjss/article/view/ 2577/2545. https://doi.org/10.5901/mjss.2014.v5n8p441

[20] Mudau, A.V., Mundalamo, F.J. \& Sedumedi, T.D.T., (2014). Through The Eye Of The Needle: A Classroom Practice Diagnostic Framework For The Teaching Of Projectile Mo- 
tion. Procedia - Social and Behavioral Sciences 131. 415 - 419. $\mathrm{http}: / / w w w . s c i e n c e d i r e c t . c o m / s c i e n c e / a r t i c l e / p i i / S 187704281403050 X$.

https://doi.org/10.1016/j.sbspro.2014.04.140

[21] Machmud, M. (2013). Heritage Media and Local Wisdom of Indonesian Society. Global Journal of Human Social Science Arts and Humanities13: 56-66. https://socialscienceresearch.org/index.php/GJHSS/article/download/854/801

[22] Meliono, I. (2011). Understanding the Nusantara Thought and Local Wisdom as an Aspect of the Indonesian Education. International Journal for Historical Studies 2. 221-234. https://www.scribd.com/document/183599704/Understanding-the-Nusantara-Thought-andLocal-Wisdom

[23] Lee, O.( 2001). Culture and language in science education: What do we know and what do we need to know?. Journal of Research in Science Teaching 38. 499-501. http://stoa.usp.br/qfl3501/files/313/1393/culture+and+language+in+science+education.pdf. https://doi.org/10.1002/tea.1015

[24] Suastra, I. W., (2010). Model Pembelajaran Sains Berbasis Budaya Lokal Untuk Mengembangkan Kompetensi Dasar Sains dan Nilai Kearifan Lokal di SMP. Jurnal Pendidikan dan Pengajaran, 43. 6-18. https://ejournal.undiksha.ac.id/index.php/JPP/ article /viewFile/1697/1484. https://doi.org/10.25273/florea.v1i1.365

[25] Orewere, B. (1991). Possible Implications of Modern Mass Media for Traditional Communication in a Nigerian Rural Setting. Africa Media Review 5. 53-65. http://pdfproc.lib.msu.edu/?file=/DMC/African\%20Journals/pdfs/africa\%20media\%20revi ew/vol5no3/jamr005003007.pdf

[26] Huth, R. (2015). A Strategy for Classroom Management Success. Journal on Best Teaching Practices 2. 4-6. http://teachingonpurpose.org/wp-content/uploads/2015/06/Huth-R.2015.-A-Strategy-for-Classroom-Management-Success.pdf

[27] Taiwo, S. (2009). Teachers' Perception Of The Role Of Media In Classroom Teaching In Secondary Schools. The Turkish Online Journal of Educationa Technology 8. 75-79. http://www.tojet.net/articles/v8i1/818.pdf

[28] Ngure, G., Begi, N., Kiman, E., \& Mweru, M. (2014). Utilization of Instructional Media For Quality Training In Pre-Primary School Teacher Training Colleges In Nairobi County, Kenya. Researchjournali's Journal of Education 2. 1-22. http://www.ku.ac.ke/schools/humanities/images/publications/798.pdf

[29] McConnell, S,. McConnell, B,. \& McConnell, K,. (2010). Mobile Devices In A ProjectBased Physics Classroom: Developing Nets-S In Students. Society for Information Technology \& Teacher Education International Conference, 1561-1565. http://www.editlib.org/p/36520/

[30] Grané, M., Olmedo, K., Crescenzi, L., \& Suárez, R. (2011). Using Mobile Devices In ELearning Programms. 1-4. https://conference.pixel-online.net/edu...pdf/ENT43-256-FPOlmedoFoE2011.pdf

[31] Mardiana, N,. \& Kuswanto, H,. (2017). Android-assisted physics mobile learning to improve senior high school students' divergent thinking skills and physics HOTS. The 4th International Conference on Research, Implementation, and Education of Mathematics and Science (4th ICRIEMS). 1-12. http://aip.scitation.org/doi/pdf/ 10.1063/1.4995181. https://doi.org/10.1063/1.4995181

[32] Hanafi, H.F., \& Samsudin, K. (2012). Mobile Learning Environment System (MLES): The Case of Android-based Learning Application on Undergraduates' Learning. International Journal of Advanced Computer Science and Applications, 3. 1-5. https://pdfs.semanticscholar.org/d89e/3718a39090531b43f05484dd5de5f0269eba.pdf. https://doi.org/10.14569/ijacsa.2012.030311 
[33] Haag, J., \& Alexsandria, V. A., (2011). From eLearning to mLearning: The Effectiveness of Mobile Course Delivery. Interservice/Industry Training, Simulation, and Education Conference. 1-13. www.adlnet.org/public/uploads/e_to_mLearning_paper.pdf

[34] Sharples, M. (2000). The Design of Personal Mobile Technologies for Lifelong Learning. Computers \& Education, 34. 177-193. http://dl.acm.org/citation.cfm?id=344484. https://doi.org/10.1016/s0360-1315(99)00044-5

[35] Hussin, S., Manap, M. R., Amir, Z., \& Krish, P., ( 2012). Mobile Learning Readiness among Malaysian Students at Higher Learning Institutes. Asian Social Science 8. 276-283. www.ccsenet.org/journal/index.php/ass/article/viewFile/20987/13717. https://doi.org/10.5 539/ass.v8n12p276

[36] Thiagarajan, S,. Semmel, D. S,. \&Semmel, M. L,. (1974). Others Instructional Development For Training Teachers Ofexceptional Children: A Sourcebook. Washington, D. C: National Center For Improvement Of Educationalsystems.

[37] Aiken, L. (1985). Three Coefficient for Analyzing the Relibility and Validity nof Rratings. Educational and Physhological Measurement 45. 131-142. http://journals.sagepub. com/doi/abs/ 10.1177/0013164485451012

[38] Hake, R. (1998). Interactive-engagement methods in introductory mechanics courses. http://www.physics.indiana.edu/ sdi/IEM-2b.pdf

[39] Alacaci, C. Lewis, S. O’Brien, G. E. \& Jiang, Z. (2010). Pre-Service Elementary Teachers' Understandings of Graphs. Eurasia Journal of Mathematics, Science \& Technology Education. 7(1). 3-14. http://www.ejmste.com/Pre-Service-Elementary-TeachersnUnderstandings-of-Graphs, 75171,0,2.html. https://doi.org/10.12973/ejmste/75171

[40] Bahtiyar, A. \& Can, B. (2016). An Investigation Of Problem-Solving Skills Of Preservice Science Teachers. Educational Research and Reviews. 11(23). 2108-2115. A Bahtiyar, B Can - Educational Research and Reviews, 2016 - academicjournals.org. https://doi.org/10.5897/err2016.3054

[41] Rakhi J,S,V. \& Somani, S. B. (2015). Android Based Smart Learning and Attendance Management System. International Journal of Advanced Research in Computer and Communication Engineering. 4. 256-260. https://www.ijarcce.com/upload/2015/june15/IJARCCE\%2055.pdf. https://doi.org/10.17148/ijarcce.2015.4270

[42] Agustina, C. \& Wahyudi, T. (2015). Aplikasi Game Pendidikan Berbasis Android Untuk Memperkenalkan Pakaian Adat Indonesia. Indonesian Journal on Software Engineering. 1. 1-8. ejournal.bsi.ac.id/ejurnal/index.php/ijse/article/download/.../481

[43] Pamungkas, A. Subali, B. \& Lunuwih, S. (2017). Implementasi Model Pembelajaran IPA Berbasis Kearifan Lokal untuk Meningkatkan Kreativitas dan Hasil Belajar Siswa. Jurnal Inovasi Pendidikan IPA. 3. 118-127. https://journal.uny.ac.id/index.php/jipi/article/ view/14562. https://doi.org/10.21831/jipi.v3i2.14562

[44] Ismail, I. Azizan, S. N.\& Azman, N. (2013). Mobile Phone as Pedagogical Tools: Are Teachers Ready? International Education Studies. $6 . \quad 36-47$. https://files.eric.ed.gov/fulltext/EJ1067762.pdf. https://doi.org/10.5539/ies.v6n3p36

[45] Alkan, F., Erdem, E. 2011. A Study on Developing Candidate Teachers' Spatial Visualization and Graphing Abilities. Procedia Social and Behavioral Sciences.15. 34463450.https://www.sciencedirect.com/science/article/pii/S187704281100862.https://doi.org/ 10.1016/j.sbspro.2011.04.316

[46] Kilic, D, Sezen, N, \& Sari, M, (2012). A Study of Pre-Service Science Teacher's Graphing Skills. Procedia-Social and Behavioral Sciences, 46, 2937-2941. www.sciencedirect.com/science/.../S18770428120.https://doi.org/10.1016/j.sbspro.2012.05 $\underline{.593}$ 
[47] Li, W. S. S., \& Arshad, M. Y. (2014). Application of Multiple Representation Levels in Redox Reactions among Tenth Grade Chemistry Teachers. Journal of Turkish Science Education, 11(3), 35-52. http://www.tused.org/internet/tused/ARCHIVE/ v11/i3/tusedv11i3s3.pdf

[48] Sirait, Hamdani, J \& Oktaviany, E. (2016). Analysis of Pre-Service Physics Teachers' Understanding of Vectors and Forces. Journal of Turkish Science Education. 14 (2). 82-85. https://www.researchgate.net/publication/318208758_Analysis_of_PreService_Physics_Te achers\%27_Understanding_of_Vectors_and_Forces

\section{Authors}

Merdu Raras is master student in Physics Education at Universitas Negeri Yogyakarta, Indonesia in 2018.

Heru Kuswanto is an Associate Professor in the Departement of Physics Education,Faculty of Mathematics and Natural Sciences, Universitas Negeri Yogyakarta, Indonesia. He passed the master program from Gajahmada University, Indonesia. Doctoral degree was obtained from Universite Jean Monnet de Saint Etienne, France.

Article submitted 2018-11-27. Resubmitted 2019-03-21. Final acceptance 2019-03-24. Final version published as submitted by the authors. 